DOI: $10.19195 / 2084-5065.50 .6$

\title{
Kuratela penitencjarna jako element strategii przeciwdziałania wtórnej przestępczości
}

\author{
KRZYSZTOF JASIŃSKI \\ ORCID: 0000-0001-8312-1147 \\ Sąd Okręgowy w Nowym Sączu
}

Kuratorzy sądowi realizują określone przez prawo zadania o charakterze wychowawczo-resocjalizacyjnym, diagnostycznym, profilaktycznym i kontrolnym w środowisku podopiecznych, a także na terenie zakładów karnych ${ }^{1}$. W jednostkach penitencjarnych kuratorzy sądowi współtworzą, a następnie realizują ,plany wolnościowe”. Jest to zespół działań poprzedzonych diagnozą potrzeb i deficytów, stanowiący wypadkową możliwości i potencjału samego osadzonego oraz braków koniecznych do zniwelowania, aby osiągnąc cel minimum — zapobiegnięcie ponownemu popełnieniu przestępstwa.

Zgłębiając rolę i zadania kuratora „penitencjarnego” (pojęcie to, choć utarte w praktyce, nie jest sformalizowane ani ukonstytuowane przepisami, należy je więc traktować wyłącznie roboczo), warto odpowiedzieć na rodzące się pytanie, co wspólnego z profilaktyką i resocjalizacją ma praca kuratora $\mathrm{w}$ więzieniu $\mathrm{z}$ osadzonym, który niebawem ma opuścić zakład karny. Przestępstwo zostało przecież wykryte, kara wymierzona i wykonana, a służba więzienna dołożyła starań, aby osadzonemu umożliwić

${ }^{1}$ Ustawa z dnia 27 lipca 2001 r. o kuratorach sądowych, Dz.U. z 2001 r. Nr 98, poz. 1071, art 1 . 
zdobycie wykształcenia, zawodu czy zaproponować udział w zajęciach o charakterze profilaktycznym lub terapeutycznym. Kurator jest za murami zakładu karnego gościem, nie prowadzi swych oddziaływań z osadzonym w sposób ciągły, ma znikomy wpływ na sytuację prawną i psychologiczną osoby odbywającej karę pozbawienia wolności (zwłaszcza nieobjętej działaniami, o których mowa w art. 164 k.k.w.), a na jego przestrzeń życiową, społeczną i rodzinną w tym czasie nie ma żadnego wpływu. Wynika to w znacznej mierze $\mathrm{z}$ faktu, że kurator sądowy wykonujący orzeczenia w sprawach karnych pracuje bezpośrednio z osobą poddaną kontroli bądź próbie. Współpraca ze środowiskiem rodzinnym i lokalnym jest aspektem nieodłącznym, lecz dodatkowym, absorbującym zabiegi kuratora poza jego podstawowymi zadaniami na rzecz sądu i zespołu kuratorskiego. Kurator wobec tego (pomijając przytoczony wyjątek) nie ma zatem podstaw prawnych, aby podczas odbywania kary pozbawienia wolności pracować z rodziną skazanego w celu przygotowania jej na powrót osadzonego. Nie byłoby to zresztą (przy wciąż wysokim obciążeniu sprawami) łatwym zadaniem. Sprawy związane z przygotowaniem osadzonych do życia po zwolnieniu stanowią przecież zaledwie niewielki procent wszystkich spraw wykonywanych w zespołach kuratorskiej służby sądowej. W obliczu przeprowadzonych w ostatnich latach zmian kodyfikacji karnej, aktualnej „filozofii penalnej” i trendów zmierzających do szerszego korzystania z kary ograniczenia wolności w miejsce kar izolacyjnych obciążenia kuratorów rzeczywiście sukcesywnie się zmniejszają. W obszarze kompetencji ustawowych kuratora wciąż jednak niewiele się zmienia. Może on podejmować działania w środowisku podopiecznego dopiero wówczas, gdy osadzony zostanie objęty „przygotowaniem do życia po zwolnieniu” w myśl art. 164 k.k.w., a kurator otrzyma formalne zlecenie od komisji penitencjarnej. Działania te przewidziane są jednak na 6 miesięcy przed planowanym zwolnieniem z zakładu karnego lub uzyskaniem warunkowego przedterminowego zwolnienia ${ }^{2}$. Gdy okres izolacji jest długi, a życiorys osadzonego skomplikowany — dający podstawy, aby sądzić, że zaplecze socjalne i rodzinne nie będzie należycie wspierać procesu readaptacji - 6 miesięcy może okazać się czasem zbyt krótkim. Nie zawsze też kurator

2 Ustawa z dnia 6 czerwca 1997 r. Kodeks karny wykonawczy, Dz.U. z 2018 r. poz. 652 , art. $164 \S 1$. 
ma na swe działania aż pół roku. Bywa, że zlecenie uprawniające go do podjęcia działań otrzymuje zaledwie na 1-2 miesiące przed zwolnieniem. Niemniej jednak skuteczna pomoc w ponownej adaptacji do warunków wolnościowych sprzyja zmniejszeniu ryzyka recydywy. Ma to szczególne znaczenie w wypadku recydywistów. Przytoczone niżej badania dowodzą, że ta grupa bardzo szybko dopuszcza się ponownego naruszenia porządku prawnego. Zdaje się temu sprzyjać mniej perspektyw i możliwości legalnego rozwiązywania problemów egzystencjalnych, jak również wypracowany przez lata i utrwalony schemat funkcjonowania w społeczeństwie.

Przyglądając się bliżej roli kuratora „penitencjarnego" w procesie readaptacji oraz jego udziałowi w profilaktyce przestępczości, warto odwołać się do dynamiki skazań i współczynnika przestępczości zbadanego w latach 2012-2015 przez Departament Strategii i Funduszy Europejskich Ministerstwa Sprawiedliwości. Wykazano, że największe wartości w tym względzie odnotowano w pierwszym roku od pierwotnego skazania, a więc największą skłonność do ponownego popełnienia przestępstwa sprawcy wykazują w pierwszym roku od poprzedniego czynu. Zasada ta dotyczy zarówno ogólnej liczby osób skazanych, jak i osób pierwotnie skazanych na karę ograniczenia wolności, grzywnę samoistną czy wreszcie karę pozbawienia wolności, która jest „osią” zabiegów i starań podejmowanych przez kuratorów penitencjarnych ${ }^{3}$. Nie jest również tajemnicą, że na ponad 70 tys. osób osadzonych w 2017 roku w Polsce blisko 38 tys. to recydywiści penitencjarni, a więc osoby, które w przeszłości były już poddane oddziaływaniom korekcyjnym w warunkach izolacji ${ }^{4}$. Czy jednak samo stworzenie przestrzeni do normalnego funkcjonowania w społeczeństwie po opuszczeniu murów więziennych można uznać za działania o charakterze profilaktycznym? Zdaniem autora tak, ponieważ zapobiega to ich powrotowi do działalności przestępczej, a przynajmniej zmniejsza szansę na ponowne naruszenie norm prawnych i społecznych poprzez redukcję sprzyjających temu okoliczności. Jednostka sfrustrowana, bez perspektyw i nadziei na lepsze jutro chętniej sięgnie do utartych, nieakceptowanych, lecz dobrze znanych wzorców zachowań. Jest

3 Powrotność do przestępstwa w latach 2009-2015, Departament Strategii i Funduszy Europejskich, Wydział Statystycznej Informacji Zarządczej, Warszawa 2017, s. 1.

4 Statystyka Sądowa - Prawomocne skazania osób dorostych 2012-2016 Edycja II; Departament Strategii i Funduszy Europejskich, Warszawa 2017, s. 14. 
to przecież łatwe, a skoro nie ma do czego wracać, a do stracenia nie ma wiele, łatwo przewidzieć dalszy bieg historii takiego człowieka.

Warto również zadać sobie pytanie, czy „powrót do przestępstwa” może być w pewnym sensie ,,papierkiem lakmusowym” kondycji społecznej, zwłaszcza w obliczu informacji, że wiele przestępstw popełnianych jest w warunkach recydywy. Z przytoczonych analiz wynika, że w latach 2009-2015 odsetek recydywistów (definiowanych przez art. 64 § 1 i 2 k.k.) wzrastał w stosunku do ogólnej liczby prawomocnie skazanych osób. W 2009 roku wyniósł on 3,5\%, a w 2015 — 5,6\%. Z ogólnej liczby 373542 prawomocnie skazanych w 2011 roku 95248 osób dorosłych ponownie popełniło przestępstwo w ciągu kolejnych 5 lat, co stanowi 25,5\% ogółu skazanych. W około połowie przypadków przestępstwo jest ponownie popełnianie w pierwszym roku po uprawomocnieniu się poprzedniego wyroku. Najwięcej osób, które powracały do przestępstwa w okresie od 2011 do 2015 roku, pierwotnie skazywanych było na karę bezwzględnego pozbawienia wolności - 33,7\%. Spośród 49797 osób, które w 2011 roku opuściły zakłady karne lub areszty śledcze, 40,1\% (czyli 19973 osoby) ponownie popełniło przestępstwo w ciągu 5 lat ${ }^{5}$. Liczba osób, które w ciągu 5 lat powróciły do przestępstwa, wynosi zatem 25\% wartości wszystkich prawomocnych skazań na karę pozbawienia wolności (wszystkie rodzaje) oraz grzywny samoistnej i kary ograniczenia wolności, przy czym współczynnik ten jest wyraźnie wyższy pośród osób skazanych pierwotnie na bezwzględną karę pozbawienia wolności i wynosi około 33\%. Jeszcze pesymistyczniej przedstawia się współczynnik osób powracających do przestępstwa w okresie po opuszczeniu zakładu karnego lub aresztu śledczego (po odbyciu kary w całości lub uzyskaniu warunkowego przedterminowego zwolnienia). Z przytoczonych badań wynika, że ponad $40 \%$ osób opuszczających zakłady karne w ciągu następnych 5 lat powtórnie popełnia przestępstwo. Jest to problem, a zarazem asumpt do rozwoju kurateli penitencjarnej. Nie musi być ona służbą wyodrębnioną, aby być skuteczna, ale powinna być formacją obecną w każdej jednostce penitencjarnej, wspierającą działania zarówno korekcyjne, jak i postpenitencjarne, oddziaływania pomocowe.

5 Powrotność do przestępstwa w latach 2009-2015 „.., s. 3.

Nowa Kodyfikacja Prawa Karnego 50, 2018 (C) for this edition by CNS 
Przemawia za tym kolejny argument. Otóż koszty społeczne recydywy są niewspółmierne do nakładów poniesionych na jej zapobieganie. Trzeba pamiętać, że wliczamy w nie tylko koszty postępowań karnych wobec powracającego na drogę przestępczą człowieka (w wielu wypadkach sądy zwalniają z ponoszenia kosztów skazanego na etapie wykonawczym postępowania karnego), lecz także wiele innych składowych: koszty leczenia i wsparcia ofiar/pokrzywdzonych przestępstwem, pozasądowe koszty proceduralne, utrzymanie służb porządkowych, probacyjnych i penitencjarnych, materialne straty $\mathrm{w}$ mieniu publicznym oraz utrzymanie samego osadzonego w jednostce penitencjarnej. W roku 2017 wynosiło ono 3433,17 zł miesięcznie za osobę, a w skali roku utrzymanie całej populacji więziennej kosztowało państwo polskie 3040 707,00 zł . Społeczeństwa wysoko rozwinięte i zamożne częściej stawiają na profilaktykę i zapobieganie niż na likwidację szkód. Z danych ONZ HDI (Human Development Index) wynika, że na 100 tys. mieszkańców w naszym kraju przypada aż 191 więźniów, natomiast u naszego zachodniego sąsiada jest to już tylko 78 osób na 100 tys. mieszkańców, mimo że kraj ten cechuje znacznie wyższa gęstość zaludnienia ${ }^{7}$. Kurator penitencjarny mógłby w tych okolicznościach być koordynatorem (zapoczątkowanych w dniu osadzenia) działań readaptacyjnych kontynuowanych na wolności - ogniwem systemu przeciwdziałania przestępczości wtórnej. Ciągłość i logiczna zbieżność zaplanowanych wobec skazanego oddziaływań jest zjawiskiem pożądanym. Wysiłki służby więziennej nie muszą iść przecież na marne tylko dlatego, że za murami kończy się jej odpowiedzialność, starania kuratora zaś nie muszą być skazane na porażkę z uwagi na nieadekwatność czasu, w którym je podejmie, i brak wpływu na planowanie całego procesu. Wychowawca do spraw pomocy postpenitencjarnej może współtworzyć z kuratorem penitencjarnym wzajemnie wspierający się zgrany duet. Mogą być partnerami i liderami — każdy $\mathrm{z}$ nich na innym etapie, ale ramię w ramię. Są okręgi sądowe, w których ich współpraca tak się właśnie układa.

6 A. Zientarska, M. Milewska, Wybrane zagadnienia statystyczne, Biuro Informacji i Statystyki Służby Więziennej, Warszawa 2018.

7 Raport ONZ: United Nations Development Programme, Human Development Reports, http://hdr.undp.org/en/indicators/128306 (dostęp: 20.05.20019). 
W Polsce zatrudnionych jest około 5205 (stan na 2016 rok) kuratorów zawodowych, ale tylko 3123 to kuratorzy zawodowi dla dorosłych, mający narzędzia prawne i kompetencje do bezpośredniej pracy z osadzonymi i zwalnianymi z zakładów karnych czy aresztów śledczych ${ }^{8}$. Problem w tym, że populacja więzienna (według danych statystycznych CZSW na koniec 2017 roku) to blisko 74 tys. osób, a więc średnio na jednego kuratora zawodowego dla dorosłych przypadało blisko 24 osadzonych (nie licząc zdecydowanej większości ich podopiecznych pozostających na wolności). Gdy dodatkowo weźmiemy pod uwagę rotację osadzonych w zakładach karnych w ciągu całego roku, to liczba ta ulegnie podwojeniu, a więc wyniesie blisko 50 osadzonych na kuratora w ciągu roku. Nie sposób wyrazić liczbami stopnia zaangażowania statystycznego kuratora zawodowego w świadczenie pomocy postpenitencjarnej rozumianej szerzej niż tylko jako samo udzielenie zapomogi. Zaangażowanie kuratora „penitencjarnego" w działalność organizacji pozarządowych i punktów, w których wspiera się byłego więźnia i jego rodzinę materialnie, specjalistycznie i pozamaterialne, jest jednak zjawiskiem zdecydowanie pożądanym. Organizacje pozarządowe stwarzają bowiem przestrzeń do realizacji zadań i pomysłów, na które w tak sformalizowanej instytucji jak sąd nie ma przecież miejsca.

W konfrontacji z ograniczeniami rynku pomocowego kurator penitencjarny niewiele by zdziałał, gdyby nie wspierające jego prace z byłym lub przygotowywanym do zwolnienia więźniem organizacje pozarządowe. Problem jednak w tym, że spośród 100 tys. wszystkich organizacji pozarządowych zarejestrowanych w Polsce z dofinansowania działań na rzecz byłych więźniów i ich rodzin $w$ obszarze pomocy postpenitencjarnej skorzystało w 2017 roku zaledwie 27 z nich ${ }^{9}$. Do konkursu przystąpiło niewiele więcej organizacji. Martwi zatem malejące zainteresowanie tym obszarem trzeciego sektora. Być może warto byłoby zmienić

${ }^{8}$ Kuratorska Służba Sądowa w Polsce, według stanu na dzień 31 grudnia 2016 r., Opracowanie Komisji ds. Monitorowania Warunków Pracy, Płac i Obciążeń Obowiązkami Kuratorów Krajowej Rady Kuratorów Sądowych, Warszawa 2017.

9 Wyniki otwartego konkursu ofert na powierzenie realizacji w roku 2017 zadania publicznego — pomoc postpenitencjarna, https://bip.ms.gov.pl/pl/dzialalnosc/funduszsprawiedliwosci/pomoc-postpenitencjarna/ (dostęp: 20.05.2019). 
wysokość dotacji możliwej do uzyskania w części dotyczącej pomocy postpenitencjarnej, która w przypadku organizacji nieprowadzącej schroniska mogła dotąd wynieść nie więcej niż 50 tys. zł rocznie. Ponadto stowarzyszenia czy fundacje prowadzące stacjonarne ośrodki nie są w stanie utrzymać ich ze środków tego funduszu, bo maksymalna wysokość dotacji na poziomie około $80-90$ tys. zł jest zbliżona do budżetu przeciętnej, niespecjalnie zamożnej polskiej rodziny. Z danych GUS za rok 2017 wynika, że przeciętny miesięczny przychód na jedną osobę w gospodarstwach domowych wyniósł 2009,02 zł ${ }^{10}$. Jeśli przyjmiemy, że przeciętna polska rodzina składa się z trzech osób, jej roczny przychód na podstawie danych GUS wyniesie blisko 73 tys. zł. Organizacja pozarządowa prowadząca schronisko z rotacyjnymi miejscami dla kilkunastu więźniów otrzyma dla porównania około 80 tys. zł. Pamiętając, że zasadniczo takiej pomocy udziela się przez 3 miesiące od zwolnienia, liczba skazanych, którzy w ciągu roku skorzystają z pomocy takiego ośrodka, wyniesie co najmniej kilkadziesiąt osób. Dotacja z tego źródła jest więc zdecydowanie niewystarczająca.

Przy tej okazji warto przyjrzeć się bliżej wydatkowaniu środków na udzielanie pomocy postpenitencjarnej przez jednostki penitencjarne. Te zwiększają się z roku na rok. W latach 2017-2012 było to odpowiednio: 10540369 zł, 9698974 zł, 9339507 zł, 9216251 zł, 7727019 zł i $7784182 \mathrm{zl}^{11}$. Choć korelacja między recydywą a środkami wydatkowanymi w jednostkach penitencjarnych $\mathrm{w}$ ostatnich latach wskazuje na proporcjonalność odwrotną (corocznie zwiększające się nakłady na świadczenie wparcia postpenitencjarnego i zmniejszająca się liczba recydywistów odbywających w tym czasie karę), to warto poznać wydatkowanie tychże środków przez udzielający takiego wsparcia trzeci sektor oraz samych kuratorów sądowych. Znaczna, jeśli nie większa, część faktycznego wsparcia postpenitencjarnego (choć często zapoczątkowana

10 Średnie miesięczne przychody na 1 osobę w gospodarstwach domowych wg grup społeczno ekonomicznych w Budzety gospodarstw domowych w 2017 r., Główny Urząd Statystyczny, Warszawa 2018, s. 112, https://stat.gov.pl/obszary-tematyczne/warunki-zycia/dochody-wydatki-i-warunki-zycia-ludnosci/budzety-gospodarstw-domowych-w-2017-r-,9,12.html (dostęp: 20.05.2019).

11 Roczna Informacja Statystyczna za lata 2017-2012 r., Centralny Zarząd Służby Więziennej, s. 23. 
jeszcze w trakcie odbywania kary na podstawie założenia planu, o którym mowa w art. $164 \S 1$ k.k.w. ${ }^{12}$ ) odbywa się w środowisku wolnościowym, a więc już po odbyciu kary i właśnie dlatego istotną rolę odgrywają tutaj kuratorska służba sądowa oraz organizacje pozarządowe, działające również poza murami więzienia, a więc tam, gdzie służba więzienna nie ma prawnych możliwości się poruszać. A to przecież pierwsze chwile po przekroczeniu bramy więziennej determinują kolejne miesiące i lata w życiu człowieka, zwłaszcza recydywisty, który ma utarte schematy i ścieżki oraz nawiązane i utrwalone relacje w środowisku przestępczym. Proces decyzyjny w tych okolicznościach trwa krótko, jego konsekwencje zaś mają wpływ na długie lata. Zderzenie z rzeczywistością po długotrwałej izolacji zawsze jest trudne i rzadko kiedy zachęca osobę wycofaną ze społeczeństwa i przez lata pozbawioną kompetencji społecznych do działań wymagających aktywności, wytrwałości, cierpliwości, ciężkiej pracy czy odporności na niepowodzenia. To, co trudne, wymagające samozaparcia, czasochłonne i często nieprzyjemne, jest zwykle odkładane na potem, jest to zresztą naturalna skłonność każdego człowieka. Tylko że w przypadku osób z grupy wysokiego ryzyka odkładanie starań na później może źle się skończyć. To jest właśnie przysłowiowe „5 minut” dla kuratora penitencjarnego i jego starań.

Szukanie pomocy i rozwiązań przez byłego, długotrwale izolowanego więźnia zdaje się przypominać układankę 1000 puzzli, z których wiele elementów do siebie nie pasuje. Niektóre z nich, choć pasować powinny, zostały w trakcie układania uszkodzone lub zniszczone poprzez usilne, powielane i niewłaściwe próby, schematy zachowań. W jednym miejscu zaczyna wyłaniać się zarys perspektywy jutra, ale w innym pogłębia się chaos. Te puzzle symbolizują możliwości pomocy, źródła i zasoby byłego osadzonego. Aby jednak ułożyć pełen obraz, potrzeba cierpliwości, wytrwałości w dążeniu, odporności na frustrację oraz pewnego poziomu intelektu, o motywacji wewnętrznej nie wspominając. Wiemy jednak, że nie są to cechy charakteryzujące sylwetkę przeciętnego klienta ośrodka pomocy postpenitencjarnej. Współpraca z osadzonym bywa trudna również $\mathrm{w}$ trakcie pobytu w izolacji penitencjarnej. W tych okolicznościach już na pierwszym spotkaniu warto dać się skazanemu ,wygadać”. To,

12 Dz.U. z 2018 r. poz. 652.

Nowa Kodyfikacja Prawa Karnego 50, 2018

(C) for this edition by CNS 
choć wymaga cierpliwości, buduje zaufanie i wzajemny szacunek, ale stanowi też namacalny dowód otwartości na jego problemy. Należy przy tym być ostrożnym, żeby nie stać się podmiotem manipulacji i biernym odbiorcą kreowanej i ubarwianej przez osadzonego rzeczywistości. Osadzeni mają bowiem silną skłonność do racjonalizowania, projektowania czy zniekształcania faktycznego źródła ich problemów. Uruchamiają co zresztą zrozumiałe $\mathrm{w}$ tych okolicznościach - wiele mechanizmów obronnych, mogących poprowadzić kuratora „penitencjarnego” fałszywym tropem. Rolą kuratora na spotkaniu jeszcze w zakładzie karnym jest więc w pierwszej kolejności pomóc „wyłuszczyć” faktyczny problem i uświadomić fundamentalne braki. Bywa jednak, że kurator staje się w „rękach” osadzonego narzędziem do manipulowania administracją. Osadzeni przychodzą czasem na spotkania z kuratorem z wieloma trapiącymi ich problemami, przy czym w trakcie rozmowy okazuje się, że zamierzają starać się na przykład o warunkowe przedterminowe zwolnienie, przerwę w karze lub inne przywileje, a sygnalizowane problemy nie są dla nich tak istotne, jak pierwotnie to przedstawiali. Współpraca $\mathrm{z}$ kuratorem $\mathrm{w}$ ich mniemaniu zdaje się natomiast uwiarygadniać ich dążenia przed sądem czy administracją. Czasem też osadzony z rozmowy z kuratorem wynosi dokładnie to, po co przyszedł, lecz nie dlatego, że to usłyszał, ale dlatego, że bardzo chciał to usłyszeć. Cokolwiek zostanie takiemu osadzonemu przedstawione, interpretowane będzie w kierunku oczekiwań, a nie faktów. Takie sytuacje powodują nieporozumienia, skargi, żal do osoby kuratora, dlatego warto komunikować się prostym, zrozumiałym językiem oraz być wobec rozmówcy szczerym. Już na samym początku warto też zaznaczyć, że spotkanie z kuratorem nie ma nic wspólnego z ułatwieniem wcześniejszego zwolnienia, ma jedynie sprzyjać lepszemu funkcjonowaniu po zwolnieniu. Nawet najlepszy kurator „penitencjarny” zmaga się w dodatku z własnymi i systemowymi ograniczeniami, dlatego nie powinien też składać obietnic „bez pokrycia”.

Na tym tle ciekawą grupę osadzonych stanowią skazani za przestępstwa przeciwko rodzinie, zwłaszcza za przemoc domową. Oni najczęściej utożsamiają swoje problemy i trudności z osobą ofiary, przerzucając na nią winę za swoją aktualną sytuację. Jest to pewna forma obrony własnego wizerunku poprzez uruchamianie mechanizmów obronnych, któ- 
rej można by poświęcić odrębny artykuł, a może nawet książkę. Napisali zresztą o tym twórcy „teorii neutralizacji” D. Matza i G. Sykez.

W odniesieniu do kurateli ,penitencjarnej” jako idei uniwersalnej o zasięgu globalnym warto nakreślić również jej kontekst lokalny z obszaru działalności autora, chociażby dlatego że ewoluowała ona jako przykład wspomnianej współpracy z organizacją pozarządową, która co ciekawe - nie jest organizacją branżową. Właściwość terytorialna Sądu Okręgowego w Nowym Sączu obejmuje podległe Sądy Rejonowe w Gorlicach, Limanowej, Nowym Sączu (z wydziałem zamiejscowym w Muszynie), Nowym Targu i Zakopanem. Administracyjnie są to zatem powiaty gorlicki, limanowski, nowosądecki, nowotarski i tatrzański. W ich skład wchodzi 48 gmin o łącznej powierzchni około $5600 \mathrm{~km}^{13}$ i ludnością na poziomie około 890 tys. mieszkańców. Jeszcze w 2015 roku wskaźnik zagrożenia przestępczością w Nowym Sączu był najwyższy w województwie i mieścił się w granicach 4303,1-5414,6 na 100 tys. mieszkańców ${ }^{14}$. Problemem doskwierającym kuratorom ,penitencjarnym" był do 2014 roku brak organizacji aktywnie wspierających pracę z osadzonymi i zwalnianymi. W 2014 roku powołano w mieście Centrum Pomocy Postpenitencjarnej, które jest punktem konsultacyjnym działającym stacjonarnie (w siedzibie stowarzyszenia) oraz obecnym na terenie trzech zakładów karnych w Nowym Sączu, Tarnowie oraz Trzebini, gdzie przedstawiciele centrum (kurator, prawnik, doradca zawodowy oraz pracownik socjalny) systematycznie spotykają się z osadzonymi, konsultują ich sytuację, diagnozują potrzeby oraz proponują rozwiązania. Status organu prowadzącego centrum — pozyskującego na działalność środki z Funduszu Sprawiedliwości — przyjęło Stowarzyszenie Sursum Corda w Nowym Sączu. Organizacja ta dała się poznać jako solidny partner, choć większość pozostałych obszarów jej działania skupia się zasadniczo wokół innych grup docelowych (niepełnosprawni, młodzież). Od tamtej pory kuratorom okręgu nowosądeckiego udało się również potroić ilość wydatkowanych środków na pomoc postpenitencjarną w okręgu, choć wartości liczbowe w zestawieniu z innymi większymi okręgami sądo-

13 Wyliczenia własne na podstawie informacji poszczególnych samorządów terytorialnych.

14 Przestępczość w województwie Małopolskim w 2015 r., Urząd Statystyczny w Krakowie, Małopolski Ośrodek Badań Regionalnych, dane za rok 2015. 
wymi nie są zapewne imponujące. Kuratorzy okręgu starają się przy tym wydatniej wspierać rodziny osadzonych — średnia wartość zapomogi dla członka rodziny osoby zwalnianej lub osadzonej w okręgu nowosądeckim była o 43\% wyższa niż dla samego skazanego.

Zasadniczo dla skutecznej realizacji zadań kurator „penitencjarny” powinien być łącznikiem, koordynatorem, specjalistą, lecz także towarzyszem $w$ drodze. $\mathrm{W}$ ocenie autora przeszkadza $\mathrm{w}$ tym stygmatyzacja wynikająca z faktu, iż na co dzień kurator sądowy kojarzy się opresyjnie, rozlicza, egzekwuje obowiązki, świadczenia pieniężne i inne powinności na rzecz pokrzywdzonych, składa wnioski o zarządzenie wykonania kary zawieszonej bądź też wnioskuje o odwołanie warunkowego przedterminowego zwolnienia. Specjalizacja kurateli, sformalizowanie roli kuratora „penitencjarnego” oraz reorganizacja pracy zespołów kuratorskich prawdopodobnie pozwoliłyby uniknąć lub chociażby zredukować ryzyko takich dysonansów. Jednocześnie nadmierna regulacja wiąże się z wieloma innymi trudnymi do przewidzenia ryzykami.

W realizacji działań readaptacyjnych na poziomie lokalnym nie pomagają również pewne niedobory w koordynacji, na które zwraca uwagę Najwyższa Izba Kontroli w raporcie poświęconym readaptacji skazanych na wieloletnie kary pozbawienia wolności z 2015 roku. W ocenie autorów raportu ,system w zakresie wsparcia społecznej readaptacji skazanych, w tym skazanych na wieloletnie kary pozbawienia wolności nie jest kompleksowy i nie stanowi ustrojowej całości"15. Działalność odpowiedzialnych za ten obszar służb nie jest skoordynowana, obecna organizacja systemu nie w pełni zaś sprzyja reintegracji ze społeczeństwem. Rady Terenowe do spraw Readaptacji Społecznej i Pomocy Skazanym zdają się nie funkcjonować w sposób wystandaryzowany czy choćby jednolity. Czy zatem koordynator na poziomie lokalnym w osobie kuratora „penitencjarnego” byłby złą propozycją na zauważone braki? Przecież zespoły kuratorskiej służby sądowej wykonujące orzeczenia w sprawach karnych (bądź zespoły połączone) funkcjonują w strukturach każdego z blisko 320 sądów rejonowych w kraju. Specjaliści są więc obecni na każdym szczeblu lokalnym. Może warto zaangażować ich i zaprosić do

15 Readaptacja spoleczna skazanych na wieloletnie kary pozbawienia wolności, Informacja o wynikach kontroli, Departament Porządku i Bezpieczeństwa Wewnętrznego Najwyższej Izby Kontroli, Nr ewid.177/2015/P/14/044/K, Warszawa 2015, s. 11. 
współtworzenia systemu u podstaw. Katedra Pomocy Postpenitencjarnej i Wychowania do Pracy Instytutu Spraw Społecznych Uniwersytetu Pedagogicznego w Krakowie od dwóch lat kształci absolwentów na kierunku koordynator pomocy postpenitencjarnej. W oddolnych inicjatywach tkwi więc potencjał, który warto wykorzystać w rozwiązywaniu problemów globalnych.

W obszarze świadczenia skutecznego wsparcia readaptacyjnego warto starać się być dobrym rzemieślnikiem, a nie przeciętnym ,artystą”. Nie udziwniać, nie tworzyć teorii do rzeczy prostych i oczywistych, bo wypaczają sens i normę. Coś, co jest normą, nie musi nazywać się programem readaptacyjnym. Może być codziennością. Dobre rzemiosło jest kluczem, a praktyków chętnych do zaangażowania w ten niewdzięczny, ale jakże potrzebny obszar działań jest zapewne wielu. Są nimi kuratorzy sądowi.

\section{Penitentiary probation service as an element of the reoffending counteraction strategy}

\section{Summary}

Probation officers carry out tasks, defined by law, relating to education, resocialisation, diagnostics, prevention and control among offenders, also in penal institutions (Act of 27 July 2001 on Probation Officers, Journal of Laws 2001 No. 98 item 1071, Article 1). In penal institutions probation officers co-develop and then implement the so-called "freedom plans". These are sets of actions, preceded by a diagnosis of needs and deficits, which are derived from the possibilities and potential of offenders as well as shortcomings needed to be overcome in order to achieve the minimum objective - prevention of reoffending.

Keywords: probation, social readaptation, penitentiary units, non-governmental organisations. 